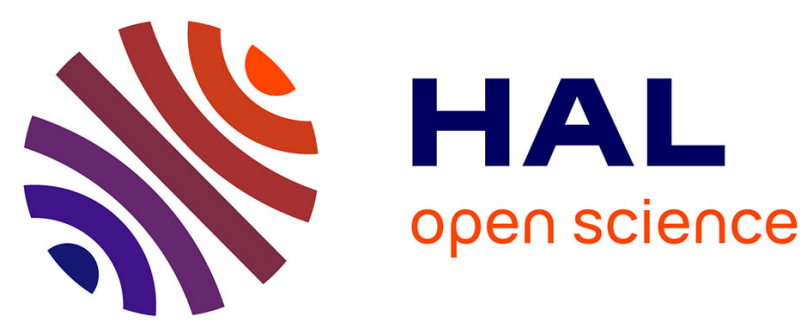

\title{
Sustainability of the transport sector during the last 20 years: evidences from a panel of 35 countries.
}

Mihail Eva, Florin Constantin Mihai, Alina-Violeta Munteanu

\section{To cite this version:}

Mihail Eva, Florin Constantin Mihai, Alina-Violeta Munteanu. Sustainability of the transport sector during the last 20 years: evidences from a panel of 35 countries.. 19th International Multidisciplinary Scientific GeoConference on Ecology, Economics, Education and Legislation SGEM 2019, Jun 2019, Albena, Bulgaria. 10.5593/sgem2019/5.1/S20.085 . hal-02196197

\section{HAL Id: hal-02196197 https://hal.science/hal-02196197}

Submitted on 27 Jul 2019

HAL is a multi-disciplinary open access archive for the deposit and dissemination of scientific research documents, whether they are published or not. The documents may come from teaching and research institutions in France or abroad, or from public or private research centers.
L'archive ouverte pluridisciplinaire HAL, est destinée au dépôt et à la diffusion de documents scientifiques de niveau recherche, publiés ou non, émanant des établissements d'enseignement et de recherche français ou étrangers, des laboratoires publics ou privés. 


\title{
SUSTAINABILITY OF TRANSPORT SECTOR DURING THE LAST 20 YEARS: EVIDENCES FROM A PANEL OF 35 COUNTRIES
}

\author{
Dr. Mihail Eva ${ }^{1}$, Dr. Florin-Constantin Mihai ${ }^{2 *}$, Dr. Alina-Violeta Munteanu ${ }^{2}$ \\ ${ }^{1}$ Faculty of Geography and Geology, Alexandru IoanCuza University of Iasi, Romania. \\ ${ }^{2}$ Department of Research, Faculty of Geography and Geology, Alexandru IoanCuza University \\ of Iasi, Romania. Corresponding author: mihai.florinconstantin@gmail.com.
}

\begin{abstract}
Between 1990 and 2015, the annual global amount of $\mathrm{CO}_{2}$ emission generated by transport has increased by $68 \%$, from around $4.6 \mathrm{GtCO}_{2}$ to around $7.7 \mathrm{GtCO}_{2}$. Technological advances towards eco-friendly vehicles and policy incentives promoting environmental-friendly modes of transport have thus been offset by economic growth and increasing mobility. This study questions the relationship between economic growth and sustainability performance of transport sector. It adds to the literature new insights concerning recent trends in the relationship between gross domestic product and various aspects of transport sustainability such as carbon footprint, carbon intensity and transport safety. A particular attention is given to discussing the emerging issues of "carbon inequality" and the role of political entities that contribute most to global $\mathrm{CO}_{2}$ emissions, such China, USA and the EU. Finally, this study adds to the literature a composite index of transport sustainability performance and explores between-country inequalities in terms of sustainability performance.
\end{abstract}

Keywords: $\mathrm{CO}_{2}$ emissions, environmental impact, OECD countries, carbon footprint, carbon inequality, road fatalities.

\section{INTRODUCTION}

During the last decades, transport sector has significantly changed the lives of millions of people around the world, boosting mobility and enabling economic development. However, it also significantly impacted the environment, despite technological advances and policy incentives promoting environmental-friendly modes of transport [1]. Nowadays, transport is a major contributor to air pollution next to energy generation and industrial manufacturing [2]. In fact, transport is among the only few sectors where emissions are constantly growing [1] [2].Between 1990 and 2015, the total amount of $\mathrm{CO}_{2}$ emission generated by transport has actually increased by 68\% [3] and major sustainable development strategies see now this sector as a priority area for sustainability. Understanding whether transport systems of various countries are heading towards or moving away from sustainability is of high importance.

It could help policy makers tracking the progress of their countries and formulate policies accordingly. Our paper aims at answering two main questions: 1) To what degree have transport activities become more or less sustainable during the last decades? 2) How large are the differences in transport sustainability performance across the selected countries? 3) Is there any convergence in carbon intensity and carbon 
footprint of transport activities among the selected countries? This paper tackles trends in 35 countries over the period 1994-2014.

\section{THEORETICAL BACKGROUND}

There are, in fact, two main approaches to sustainable transport in the literature: the ones that deal with sustainability (with concerns only for the future generations), and the ones that tackle sustainable development (with concerns for both present and future generations) [4]. Most of the researchers address the issue from the latter perspective, i.e. by also integrating 'developmental' aspects such as transport outcomes of interest to the present generation (e.g. rate of fatalities and injuries etc.) [4].On the other hand, it is worth mentioning the conceptual difference between sustainable transport and environmentally sustainable transport. Most of researchers acknowledge that sustainable transport bridges all the three dimensions of sustainability (economic, social and environmental), while the ones that focus only on the environmental dimension are usually called environmentally sustainable transport [4]. However, these theoretical definitions are still broad and an ambiguity over what exactly sustainability means still persists, both from a sectoral and territorial standpoint [5]. Indeed, sustainable transport is recognised as being a "nebulous" [4] and unclear concept, which still lacks a universally accepted definition [6]. Notwithstanding, the three-dimensional approach of sustainability in transport studies is generally accepted, although there is no general agreement over it [7] [8]. This paper will keep a three-dimensional approach in assessing transport sustainability trends.

\section{DATA AND METHODS}

This paper is searching to test whether transport sector in the selected countries is heading towards or away from sustainability, to assess how large the differences are regarding sustainability performance of transport sector across 35 countries and to test whether there is or not, any convergence process in meeting sustainability requirements. Indicator selection and data reliability are critical issues in such an endeavour.Countries included in the analysis have been selected based on data availability and reliability.

\section{Challenges in selecting appropriate sustainable transport indicators}

Governments and research centres from across the globe enrolled in a sort of course for creating and operationalizing transport sustainability indicator sets. The Joint Research Centre from within the European Commission [2] reports 55 indicators relevant for assessing the sustainability of transport activities within the EU27, grouped into five dimensions: economic, social, environmental, technical-operational and institutional. In UK, a group of researchers [6] advanced the ELASTIC methodological framework for selecting the most relevant indicators for the purpose of sustainable transport planning, conceived upon surveying the opinions of practitioners and academics. Such initiatives show that there is a high need for empirical evidences for a better understanding of recent trends and for supporting policy and planning. On the other hand, they also show that there is no general agreement on a precise set of indicators for assessing transport performance in a sustainability context. Indeed, "there are currently no standardised indicator sets for comprehensive and sustainable transport planning" [8]. Even today, this is still valid in most of the countries, especially in the developing ones, although both developed and developing countries are confronting critical issues in planning for future transport systems [7]. Nevertheless, there is some general agreement on what sustainable transport indicator sets should assess: most of them need to integrate the three-dimensional approach to sustainability (economic, social and environmental), 
which is supported by policy documents (including the EU Sustainable Development Strategy). Furthermore, most of them need to integrate both development (presentoriented) and sustainability indicators (future-oriented) [4].

\section{Indicators and data selected for the current research}

In our study, we rely on the use of what is known in the literature as transport sustainability indicators [2] [4] [6][8]. The ones chosen for our research reflect sustainability principles and help to detect whether countries move away from or towards a sustainable transport sector. For this purpose, we employ panel data (19942014) to detect trends and, thus, to conclude based on the detected trajectories. The paper does this by employing three main indexes: i) carbon intensity of transport sector (CIT), ii) carbon footprint of transport sector (CFT), and iii) transport sustainability index (TSI). Carbon intensity of transport sector is assessed as $\mathrm{CO}_{2}$ emissions from transport in tonnes per one million units of current USD GDP (latest data from OECD Transport Statistics). Carbon footprint of transport sector is assessed as $\mathrm{CO}_{2}$ emissions from transport sector in tonnes per inhabitant (latest data from OECD Transport Statistics). Transport sustainability index is a composite index that we are introducing in this paper. Its purpose is to provide a summary measure of average achievements in key dimensions of transport sustainability.

\section{Transport Sustainability Index (TSI)}

A composite index of transport sustainability is useful for having an image on the overall transport sustainability performance of countries around the world. The index that this paper advances - the TSI - aggregates several variables into one message. TSI is conceived in a similar manner to HDI (Human Development Index). It gives a summary of the sustainability level of a certain transport sector based on six indicators chosen to reflect the three dimensions of sustainability(economic, environmental and social). The three-dimensional approach is widely spread in the literature [8] [9] and it is acknowledged as the most appropriate to develop strategies and policies in the field of sustainable transport. Table 1 gives an overview of the six selected variables. They have been chosen based on their relevance for the sustainability principles (all of them are among top indicators recommended by previous papers), and based on their coverage (a minimum of 35 countries to be covered) and on their reliability and quality (data behind indicators has been extracted from the OECD Transport statistics). The six variables have been standardised in order to have all of them ranging from 0 to 100 . Equations (1), (2) and (3) explain how the six indicators have been summarised.

$$
\begin{aligned}
& T S I=100-(E n v+S o c+E C O) / 3 \\
& E n v=\left(\mathrm{CO}_{2} G D P+\mathrm{CO}_{2} \operatorname{Inh}\right) / 2 \\
& E c o=\left(\mathrm{Pas}_{R d}+\mathrm{Frg}_{R d}+\operatorname{In} v_{R d}\right) / 3
\end{aligned}
$$

Where TSI $=$ Transport sustainability performance index for country $x$ in year $y$.

The other abbreviations employed are detailed in Table 1. TSI values range from 0 (completely unsustainable) to 100 (perfectly sustainable). Being quite similar to HDI, the transport sustainability index is having approximately the same advantages and shortcomings. It is a clear and transparent index, easy to interpret and understand. It is useful in comparing, classifying and ranking countries, and it helps to shed some light on the sustainability level of various transport systems. It can serve as a guidepost in scientific analysis, policy making and general public debate. It is easy to replicate and apply in other geographical and temporal contexts, including at infranational level. 
However, it captures only part of what transport sustainability is, it does not integrate equity considerations due to lack of data covering all the selected countries, and the weighting factors to aggregate the three pillars can be challenged.

Table 1: Variable used to compute TSI

\begin{tabular}{|c|c|c|c|c|c|}
\hline Indicator & Sub-indicator & $\begin{array}{l}\text { Max value in the } \\
\text { database }\end{array}$ & $\begin{array}{l}\text { Max } \\
\text { value } \\
\text { used for } \\
\text { standardiz } \\
\text { ation }\end{array}$ & $\begin{array}{l}\text { Range of } \\
\text { the } \\
\text { standardize } \\
\text { d sub- } \\
\text { indicator }\end{array}$ & $\begin{array}{l}\text { Sub- } \\
\text { indicator } \\
\text { abbreviat } \\
\text { ion }\end{array}$ \\
\hline \multirow[t]{2}{*}{$\begin{array}{l}\text { Environm } \\
\text { ental } \\
(E n v)\end{array}$} & $\begin{array}{l}\mathrm{CO}_{2} \text { emissions from transport } \\
\text { (tonnes / } 1 \text { million units of } \\
\text { current USD GDP) }\end{array}$ & 1011 (Russia, 1999) & 1100 & $0-100$ & $\mathrm{CO}_{2} \mathrm{GDP}$ \\
\hline & $\begin{array}{l}\mathrm{CO}_{2} \text { emissions from transport } \\
\text { (tonnes / inhabitant) }\end{array}$ & $\begin{array}{l}6.1 \text { (USA, 2000, } \\
2002-2006)\end{array}$ & 7 & $0-100$ & $\mathrm{CO}_{2} \operatorname{Inh}$ \\
\hline $\begin{array}{l}\text { Social } \\
(\text { Soc })\end{array}$ & $\begin{array}{l}\text { Road fatalities } \mathrm{p} / 1 \text { million } \\
\text { inhabitants }\end{array}$ & 278 (Korea, 1996) & 300 & $0-100$ & $F A T$ \\
\hline \multirow[t]{3}{*}{$\begin{array}{l}\text { Economic } \\
(E c o)\end{array}$} & $\begin{array}{l}\% \text { of road passenger transport } \\
\text { in total inland passenger } \\
\text { transport }\end{array}$ & $\begin{array}{l}100 \text { (Iceland for the } \\
\text { entire period, } \\
\text { Mexico, 2000- } \\
2008 \text { ) }\end{array}$ & $*$ & $0-100$ & Pas_Rd \\
\hline & $\begin{array}{l}\% \text { of road freight transport in } \\
\text { total inland freight transport }\end{array}$ & $\begin{array}{l}100 \text { (Iceland, for } \\
\text { the entire period) }\end{array}$ & $*$ & $0-100$ & Frg_Rd \\
\hline & $\begin{array}{l}\% \text { of road infrastr. investment } \\
\text { in total inland transport } \\
\text { infrastructure investment }\end{array}$ & $\begin{array}{l}100 \text { (Iceland for the } \\
\text { entire period, } \\
\text { Estonia, 1996, } \\
\text { 1997) }\end{array}$ & $*$ & $0-100$ & $I n v_{-} R d$ \\
\hline
\end{tabular}

Source: authors. Notes: * No need for standardisation (the variables already range between 0 and 100).

\section{RESULTS AND DISCUSSIONS}

\section{Trends in transport sustainability across a panel of 35 countries}

Overall, TSI shows that inland transport sectors across the 35 countries included in the analysis are generally more sustainable in 2014 compared to level registered two decades before (Figure 1).However, this does not imply that transport is generating less amounts of $\mathrm{CO}_{2}$ emissions. It only means that all of the 35 economies are emitting less $\mathrm{CO}_{2}$ per unit of GDP, and 34 of them register fewer fatalities per 1 million inhabitants in 2014 compared to 1995. Moreover, 11 countries out of 35 register lower quantities of $\mathrm{CO}_{2}$ emissions per inhabitant from transport.

Taken together the three dimensions of sustainability, one could argue that the transport sector is heading towards sustainability (Figure 1). However, when looking only at the environmental dimension of sustainability, 24 countries out of 35 are emitting more $\mathrm{CO}_{2}$ in 2014 and most of them have doubled their carbon footprint. China has seen the largest increase in carbon footprint from transport $(500 \%$ increase in the level of $\mathrm{CO}_{2} /$ per inhabitant) (figure 2). The remaining 11 countries decreased their carbon footprint only slightly (values range from $-4 \%$ in Belgium to $-19 \%$ in Malta). As a consequence, total levels of $\mathrm{CO}_{2}$ emissions from the transport sector in the 35 countries significantly increased between 1994 and 2014. However, Figure 2 shows that the year 
2008 is a turning point for the developed world. In the EU28 and US, following the global financial crisis, the total amount of $\mathrm{CO}_{2}$ emissions from transport entered a decreasing trend. Even though for the US this trend stopped afterwards, it continues in the $\mathrm{EU}$, thus indicating that decreasing $\mathrm{CO}_{2}$ emissions is possible, both in relative (per inhabitant and per unit of GDP) and in absolute (in tonnes) terms.

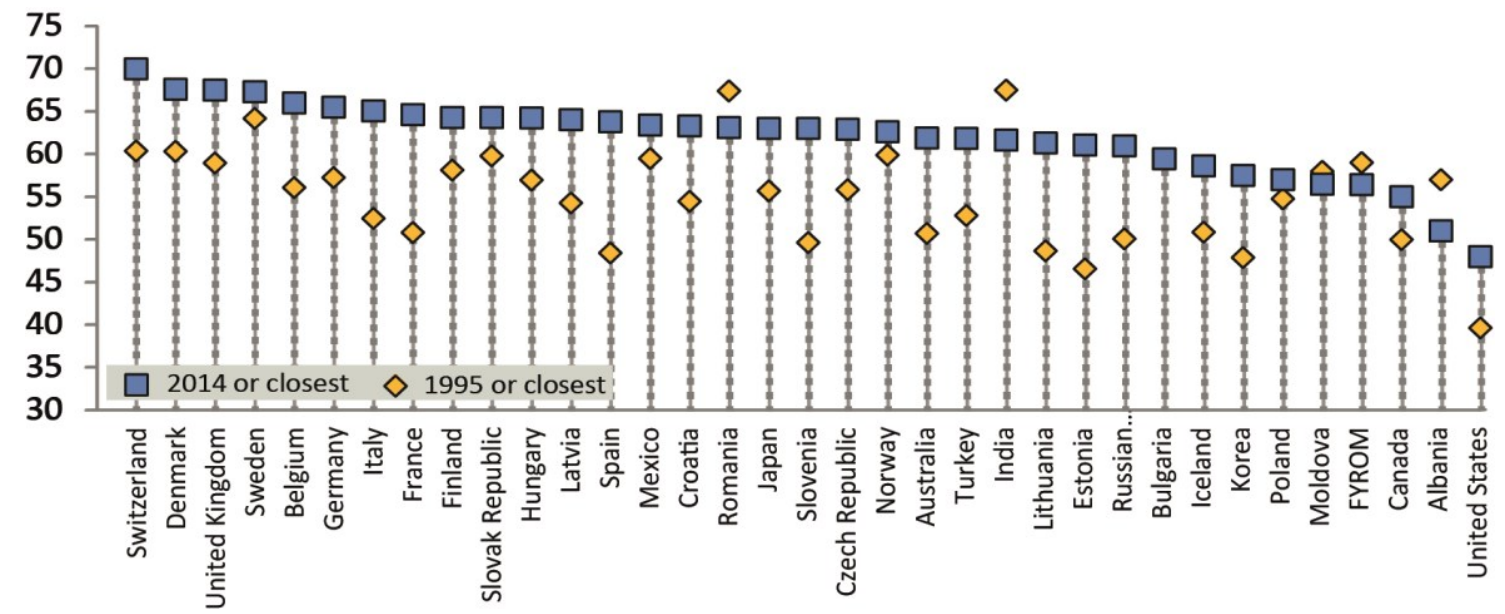

Figure 1: Transport sustainability index computed for 35 countries. Source: authors

TSI also shows that US transport sector is the least sustainable among the 35 countries included in the analysis, whilst Switzerland ranks first. US register the lowest sustainability index both in 1995 and 2014. These results contradict the findings of [7], who also developed an 'unique sustainability index' of transport across 79 countries. What is surprising is that results from [7]show that US has the most sustainable transport sector between 1980 and 1995 . However, it is not the different time framework that explains the difference in results, but the methodological approach. [7] useelasticities of non-transport variables with respect to transport variables, which show trends and dependencies, but not the state of a phenomenon. It rather shows the economic, social and environmental dependence of each country on the transport networks, which is rather different from having a sustainable transport sector.

\section{Trends in carbon footprint and carbon intensity across a panel of 35 countries}

Ranking and making comparisons across countries is highly important as the discourse on between-country inequality is gaining prominence, including from the perspective of carbon emissions [10], and unequal ecological exchanges [11].
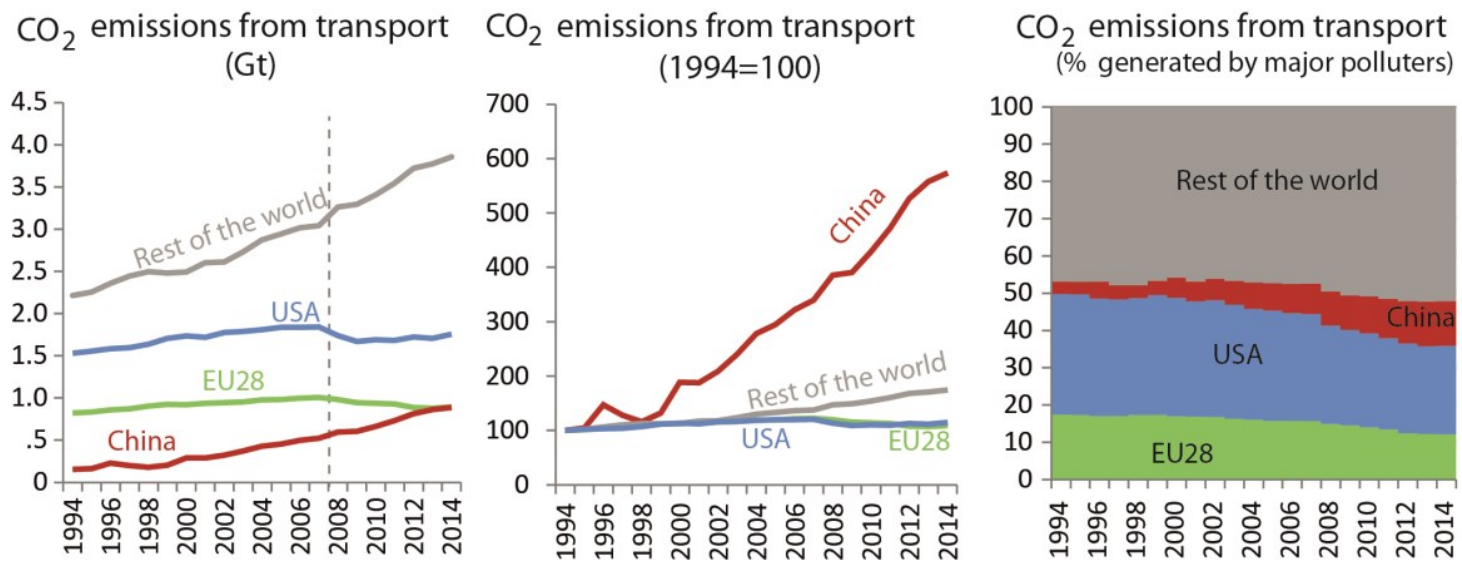

Figure 2: Trends in $\mathrm{CO}_{2}$ emission from transport in EU28, US and China. Source of graphs and calculations: authors. Data source: World Bank Database. 
Figure 3 and 4 show trends in CFT and CIT and they mostly pinpoint to facts that are in line with previous results in the literature. Figure 3 shows that CFT has increased in most of the countries included in the analysis (24/35) and that the highest increases occurred in developing countries, especially in central and eastern EU, as well as in Asian developing countries such as China and India. The scatter plot pinpoints a significant convergence process in CFT among the selected countries, i.e. inequalities between countries in levels of CFT are significantly decreasing (negative relation, $\mathrm{R}^{2}=0.576$ between CFT in 1994 and its percentage change over the following two decades). However, Figure 3 also shows that the convergence process is mainly triggered by increasing CFT in developing countries and only to a very low extent by decreasing CFT in advanced EU economies.

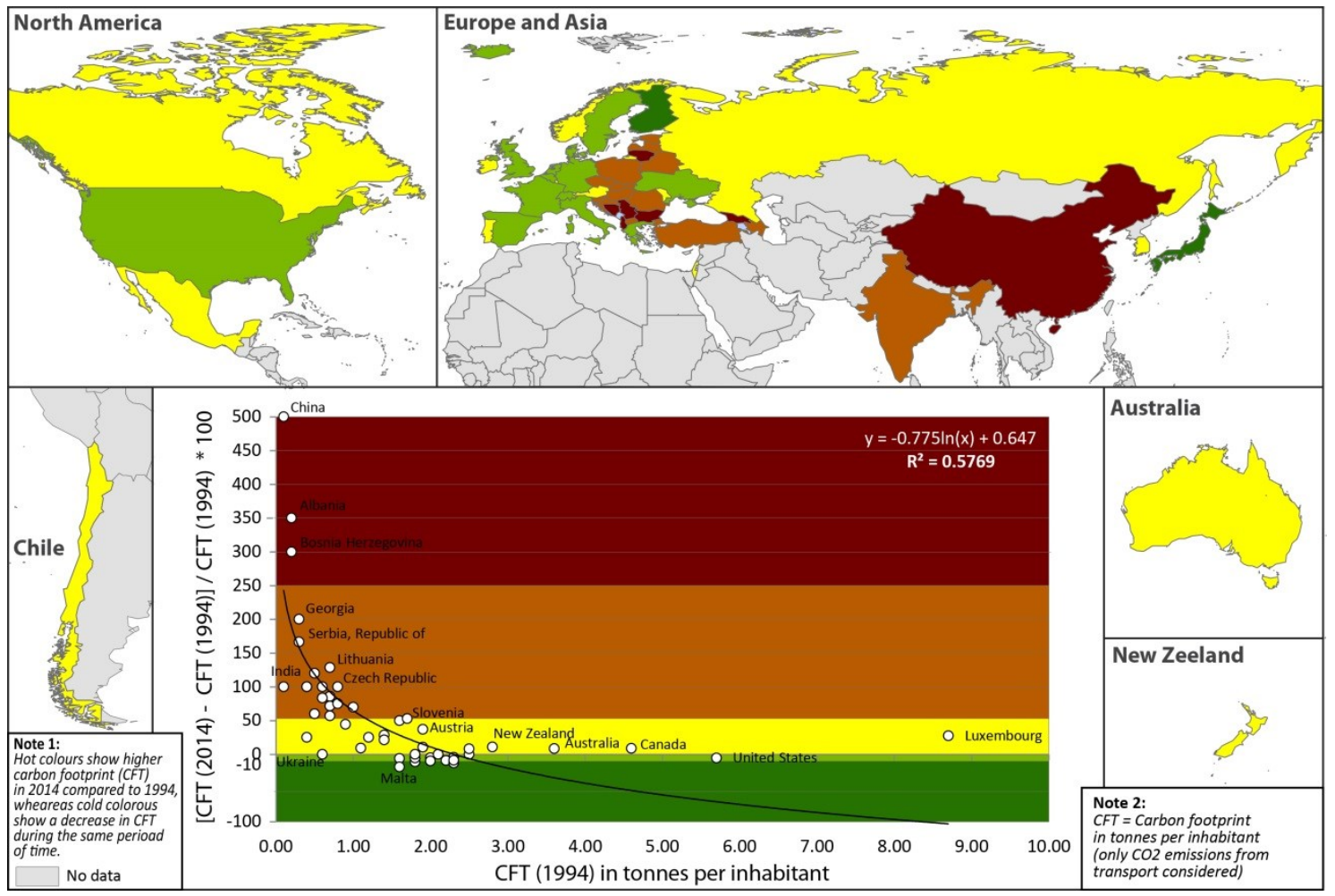

Figure 3: Changes in carbon footprint of transport (CFT) between 1994 and 2014.

On the other hand, CIT has decreased in all countries included in the analysis (figure 4). This trend indicates that both the developed and developing economies are significantly dematerialising. During 1994-2014, decreases in CIT range between -5\% in Japan and $85 \%$ in the Russian Federation. Generally, the higher the CIT in 1994, the higher the reduction in CIT during the following two decades. This also pinpoints the fact that there is a convergence process in CIT between countries included in the analysis. That might be triggered by structural changes in developing economies, where growing shares of GDP are now produced in tertiary sector, which is less transport-demanding than manufacturing. However, decreasing carbon intensities, measured as tonnes per unit of GDP, are hiding the fact that, in absolute terms, carbon emissions from transport continue to rise (figure 2). 


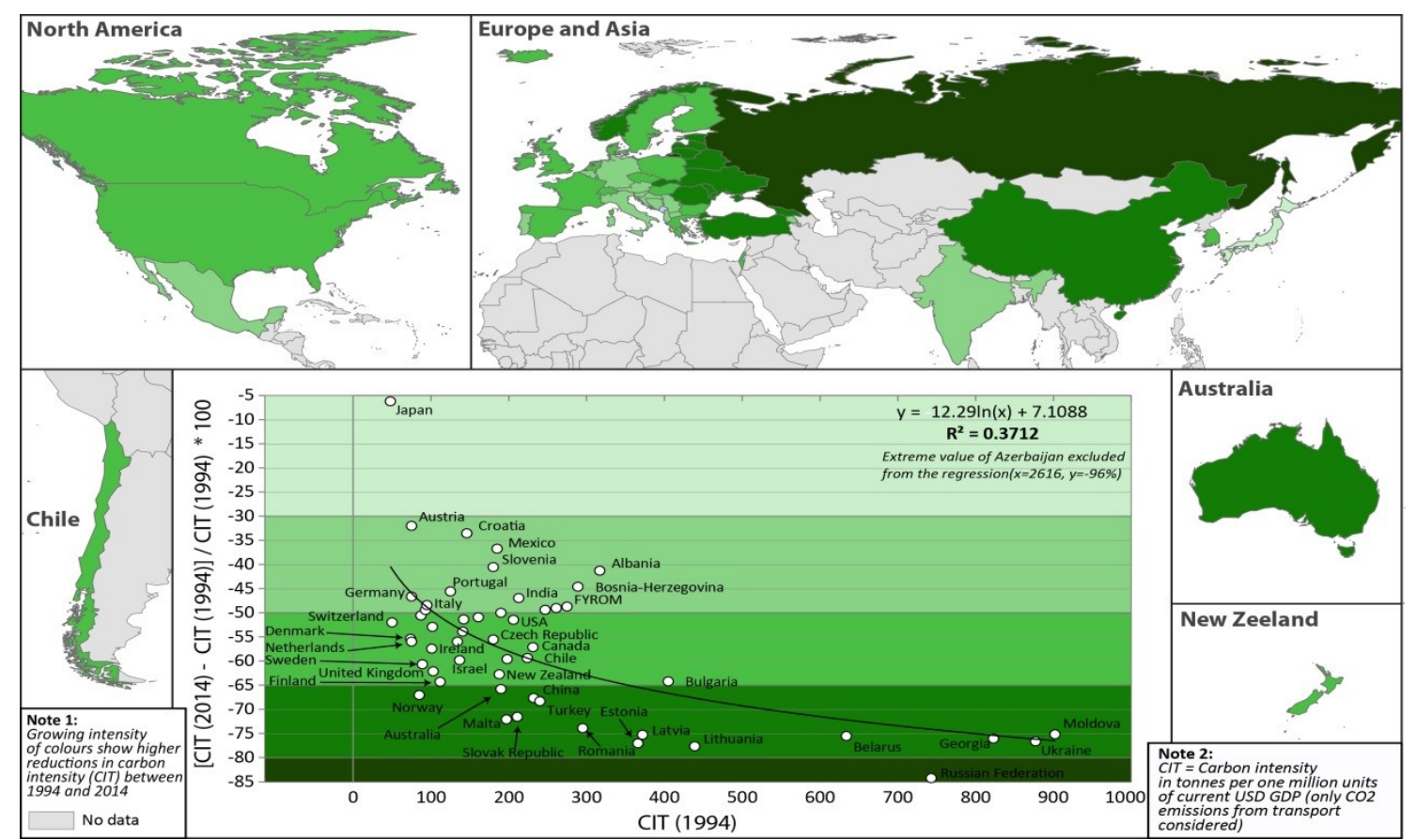

Figure 4: Changes in carbon intensity of transport (CIT) between 1994 and 2014.

The route for a widespread sustainability transport system will be a hard challenge in medium and long term in the context of climate changes (Paris Agreement), severe air pollution issues and geographical inequalities between continents, nations, regions or urban-rural gaps. Multiple and innovative industries must develop simultaneously if biofuels, electricity, and hydrogen alternatives want to compete the petroleum dominance in the transport sector [12]. The decarbonification of public transport system supported by adequate and tested policies could act as a catalyst in this regard [13]. Transport system may have a key role to meet several sustainable development goals (SDGs) under Agenda 2030 framework. Sustainability is one component of transport impact and integrated research of various effects and structure analysis of transport network is expected in following years [14].

\section{CONCLUSION}

This paper tested whether the transport sector is heading away from or towards sustainability in a panel of 35 countries, and whether there is a convergence process in carbon footprint and carbon intensity. It has also advanced a composite index for assessing the overall sustainability of transport sector in the selected countries. Results show that 30 out of 35 economies under study are heading towards sustainability, if sustainability is to be understood as the average of its three pillars.

However, this is not true for the environmental pillar of the sustainable transport. Carbon intensity measured as tonnes per unit of GDP decreased in all the countries included in the analysis, although carbon emissions in absolute terms (tonnes) gradually increased in most of the countries. Furthermore, carbon footprint from transport sector increased in 24 out of 35 case studies. Results also show that there is a convergence process in levels of carbon footprint between the 35 countries, which is mostly triggered by increasing $\mathrm{CO}_{2}$ emissions in developing countries. A similar converge process exists in terms of carbon intensity which may be triggered by faster structural changes in transition economies. Some good signs are visible as 2008 seems to be a turning point for the developed world. Following the global financial crisis, the total amount of $\mathrm{CO}_{2}$ 
emissions from transport in EU28 and US entered a slight downward trend.

\section{ACKNOWLEDGEMENTS}

F.-C. Mihai's work was supported by a grant of the "Alexandru IoanCuza" University of Iasi, within the research grants program, grant UAIC, code GI-UAIC-2017-06.

\section{REFERENCES}

[1] Chapman L., Transport and climate change: a review, Journal of Transport Geography, vol. 15, pp. 354-367, 2007.

[2] Dobranskyte-Niskota A., Perujo A., Pregl M., Indicators of Assess Sustainability of Transport Activities. Part I. JRC Scientific and Technical Reports. Luxembourg: European Communities, 2007.

[3] International Energy Agency, $\mathrm{CO}_{2}$ emissions from fuel combustion. 2017 statistics. Paris: OECD, 2017.

[4] Gudmundsson H., Sustainable transport and performance indicators, Issues in Environmental Science and Technology, vol. 20,pp. 35-63, 2004.

[5] Carrière J.-P., Hamdouch A., Iatu C., Introduction. In: Carrière, J.-P., Hamdouch, A., Iatu, C. - Développement territorial durable.Paris: Economica, pp. 13-30, 2017.

[6]Castillo H., Pitfield D.E., ELASTIC - A methodological framework for identifying and selecting sustainable transport indicators. Transportation Research Part D, vol. 15, pp. 179-188, 2010.

[7] Rassafi A.A., Vaziri M.,Sustainable transport indicators: Definition and integration. International J. of Environmental Science and Technology, vol. 2(1), pp. 83-96, 2005.

[8] Litman T.,Sutainable Transportation Indicator data Quality, Submitted for presentation at the 2010 Transportation Research Board Annual Meeting, 8p, 2009.

[9] Naganathan H., Chong W.K., Evaluation of state sustainable transportation performances (SSTP) using sustainable indicators,Sustainable Cities and Society, vol. 35, pp. 799-815, 2017.

[10]Hubacek K., Baiocchi G., Feng K., Castillo R.M., Sun L., Xue J., Global carbon inequality,Energy, Ecology and Environment, vol. 2(6), pp. 361-369, 2017.

[11] Hao F., A study of unequal carbon exchange for 89 countries between 1990 and 2015. The social Sciences Journal. 2019.In press.

[12]Sultana S., Salon D.,Kuby M., Transportation sustainability in the urban context: a comprehensive review, Urban Geography, pp. 1-30, 2017.

[13]Karjalainen L.E.,Juhola S., Framework for Assessing Public Transportation Sustainability in Planning and Policy-Making, Sustainability, vol. 11(1028), 2019.

[14]Wang L.,Xue X., Zhao Z., Wang Z,The Impacts of Transportation Infrastructure on Sustainable Development: Emerging Trends and Challenges, International Journal ofEnvironmental Research and Public Health, vol. 15 (1172), 2018. 